\title{
異性化晶出法を利用した光学分割
}

新 井和 孝 ${ }^{*}$

\section{Isomerization-Crystallization Method in Optical Resolution.}

Kazutaka ARAI*

In recent years, synthetic method by the combination of isomerization and crystallization is studied intensively, especially in the practical optical resolution. In this paper, this isomerizationcrystallization method is introduced from a point of view of practical organic synthesis. A number of examples of this isomerization-crystallization method in optical resolution, many of which were often reported as the example of second-order asymmetric transformation phenomena, are classified into following two groups, and reviewed.

(1) Epimerization-crystallization method.

(2) Racemization-preferential crystallization method.

The potentialities and difficulities of each method are also discussed. The compounds resolved by this methods are $\alpha$-amino acid derivatives, cyanohydrin derivatives, $\alpha$-aromatic carboxylic acid esters, and so on.

\section{1. はじめに}

光学活性化合物を得る方法は数多いが, 実用的な方法 は数少ない。通常工業的に用いられる方法は（1）入手 容易な光学活性な原料から誘導してゅく方法，（2）ラ セミ体を光学分割する方法，（3）不斉合成を利用する 方法などである。この総説では（2）の光学分割に属す る方法の中から異性化と晶析の組み合せを利用した方法 を紹介し，その実用的な価值をお伝えしたい1。

\section{2. 異性化晶出法}

合成法が実用的かどうかは，いろいろな観点で評価さ れる。安い原料から高収率で目的物が得られることのみ でなく, 工程数が少ないこと, 反応条件や操作条件が平 易であること, 小さな反応器で大量に合成できることな ど多くの要素を含んでいる。

例えば，光学分割の中でも最近の進歩が著しいクロマ ト的方法は分析用や微量分取用には有効であるが, 分割 したい物質の量に対して大量の充填剂を必要とし, しか も充塡剤はかなり高価であるため大量に製造する目的に は余り適さない。

これに比べ異性化 (isomerization) と晶析 (crystalli-

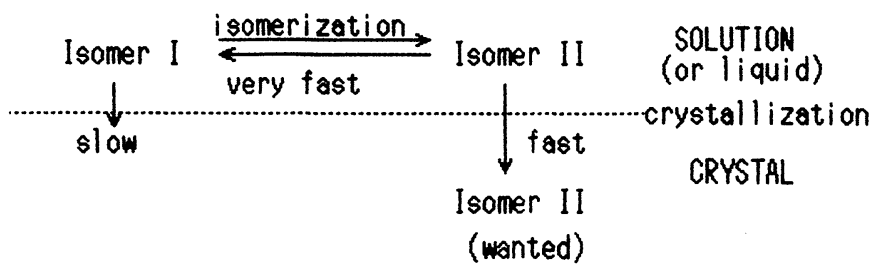

Fig. 1 Combination of the isomerization and crystallization (IC Method).

* 日産化学工業 (株) 中央研究所 (1)

* Nissan Chemical Industries Co., Ltd. (

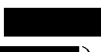


zation）を組み合せる方法（図1参照）は，操作として 異性化の反応と晶析を行うのみで, 理論的には系内を全 て目的物の結晶のみにすることも可能であるため実用的 価值が高い。

図 1 をも少し詳しく説明する。異性体 I と異性体 II を非常に速い異性化条件下で素速く平衡状態に達するよ うにしておき，目的の異性体 II のみを晶出させ，その結 晶を成長させるように工夫する。すると結晶化の進行に 伴って平衡が右へずれ，全て結晶化させると得られるの は異性体 II のみということも可能になる。結晶化させた 後で異性化の原因を除けば異性体 II の選択的合成が完了 したことになる。

以下この合成手法を異性化晶出法 (IsomerizationCrystallization Method) と呼ぶ。原理的には非常に単 純で幼稚なこの方法は，それゆえに実用的にはむしろ高 く評価される。しかし，この方法は異性化という化学反 応と晶析という工学的操作を両方とも上手に制御すると いう難しさを伴う。異性化晶出法は合成化学に汎く利用 できる手法と思われるが，ここでは光学分割への応用に 限って述べたい。

2.1. 光学分割への応用 光学分割における異性化 晶出法の発端は古く，1846 年の Dubrunfast らによる D-グルコース（1）の変旋光の発見に逆上る ${ }^{2)}$ 。この現 象はその後多くの研究がなされ解明された。1を水溶液 にすると環構造の開環，閉環が起り1位の不斉炭素にお いてェピ化 (epimerization) する（(式 1$)$ 参照) ので例
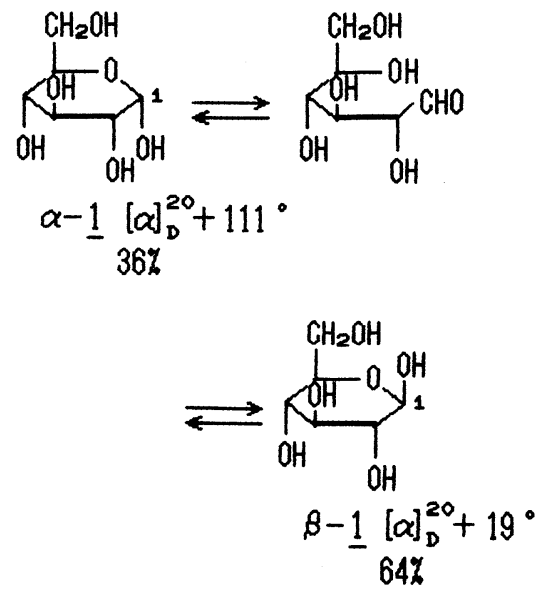

えば $\alpha-1$ の溶液の旋光度が $+111^{\circ}$ から+52。 へ時間と 共に変ることも判ってきた。このエピ化平衡にある溶液 を $35 \sim 40{ }^{\circ} \mathrm{C}$ で濃縮すると $\alpha-1$ のみが結晶として得ら れ，一方ピリジンや熱酢酸から再結晶すると $\beta-1$ の
が得られる ${ }^{3)}$ 。即ち溶液でのエピ化平衡を保ちながら一 方の異性体のみを選択的に晶析させることによって，熱 力学的に不利な異性体をも自由に得ることができる。

この例からも光学活性な化合物を得る方法として異性 化晶出法が有効であり実用的にも大きな可能性があるこ とがわかる。これは後に述べるエピ化晶出法の例に相当 する。

2. 2. 第 2 種不斉転換 ${ }^{4}$ このような現象について 従来用いられてきた言葉に不斉転換 (asymmetric transformation) がある ${ }^{4 \mathrm{~b})}$ 。不斉転換は第 1 種不斉転換 (first-order asymmetric transformation) と第 2 種不 斉転換 (second-order a.t.) に分けられる。両者はしば しば区別されずに用いられるが，前者は溶液中での互変 異性化により異性体比が変化する現象を, 後者はこの異 性化にさらに結晶化が組み合さって異性体比がさらに変 化する現象をさす。

従って先に例としてあげた D-グルコース（1）の変旋 光は第 1 種不斉転換の例になり， $\alpha-1$ のみあるいは $\beta-1$ のみの結晶が得られる現象は第 2 種不斉転換の例になる。 第 1 種不斉転換は溶液中でのラセミ化 (racemization) やエピ化平衡そのものである。

従来は光学的に不安定な化合物での現象として位置付 けられていた第 2 種不斉転換は；最近むしろ積極的にラ セミ化やエピ化を起させ光学的に不安定にして, 結晶化 と組み合せる実用的な合成手法（異性化晶出法）として 見直されてきた。それらは異性化の種類によって次の 2 つに分けられる。

（1）エピ化晶出法（ジアステレオマーが結晶化）

（2）ラセミ化優先晶出法(エナンチオマーが結晶化)

以下この順に，その難しさにもふれながら紹介する。 なお，実用的な有機合成を中心に考えて，アトロプ異性 に由来する光学活性体の例は大部分を割愛した。これら については総説があるのでそれを参照されたい゙)。

\section{3. エピ化晶出法}

エピ化晶出法は結晶化する化合物が不斉中心を二つ以 上含むジアステレオマーで, その不斉中心の一つが溶液 中で容易にエピ化し平衡に達する場合に適用できる（図 2 の例参照)。

光学分割剂を用いる, いわゆるジアステレオマー法光 学分割では, 先ず 2 種のジアステレオマーを形成し, 分 別結晶などで必要なジアステレオマーを分離する。この 際不要な側のジアステレオマーは, 通常, 光学分割剂を 除きラセミ化させて原料に戻すという煩雑な工程を要す る。しかも 1 回の収率は $50 \%$ を越えられない（図3参 


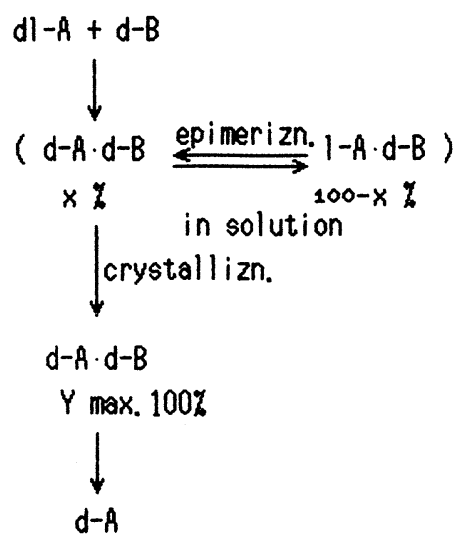

Fig. 2 An example of epimerizationcrystallization method.

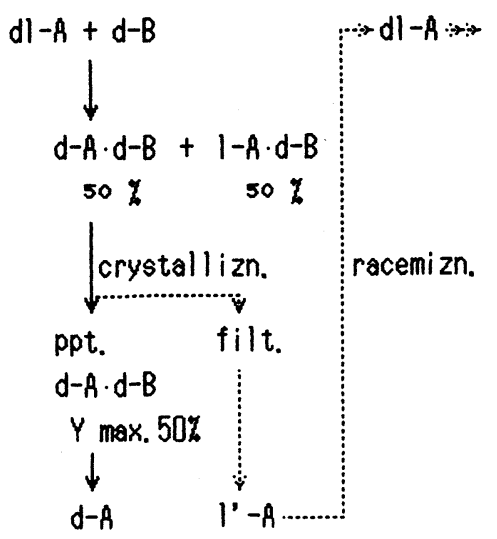

Fig. 3 An example of diastereomer method.
照)。

これに比べエピ化晶出法は不要な側のジアステレオマ 一を系内でそのままエピ化するため，1回の収率が $100 \%$ まで可能であり，しかも原料回収などの煩雑な工 程も不要である。非常に簡便な方法といえる。

3.1.エピ化晶出法の難しさ 図2や図3における $d-\mathrm{A} \cdot d-\mathrm{B}$ と $l-\mathrm{A} \cdot d-\mathrm{B}$ はジアステレオマーであり融 点, NMR, IR など全ての物性が異なる。溶解度も異な るので, $l-\mathrm{A}$ が欲しい時は $l-\mathrm{A} \cdot d-\mathrm{B}$ の溶解度の方が $d-\mathrm{A} \cdot d-\mathrm{B}$ の溶解度より小さい溶媒を用いれば良い。 実際には，望ましい溶媒が簡単には見つからないという 難しさがある。しかし問題はむしろエピ化の方法であり， その速度が結晶化の速度に比べ格段に速くできるかとい う点である。以下に述べる例でも結晶化に異常な長時間 を要している場合はこのエピ化が遅いためと考えられる。 以下，化合物の型に分け，エピ化の方法に注目しなが ら具体的に紹介する。

3.2. $\alpha$-アミノ酸誘導体 $\quad \alpha$-アミノ酸の $\alpha$ 位のエ ピ化を利用した有名な反応に Erlenmeyer 反応 ${ }^{5)}$ がある。 この反応の一例として，グリシン（2）と 2 倍モルの 4ベンジルオキシベンズアルデヒド（３）をアルコール中 で水酸化カリウム存在下に反応させた。即ち $60^{\circ} \mathrm{C}$ に加 熱し溶かした後, 室温で 5 時間放冷し, 析出した結晶を ろ過し，ベンジリデン体 4 を収率 $95 \%$ で得た。4 を酸 で処理すると $\beta$-(4-ベンジルオキシフェニル)セリン (5) が threo体のみで得られ, erythro 体は全く得ら れなかった (図4参照) $)^{6)}$ 。

これはグリシンの $\alpha$ 位の酸性度が $N-$ ベンジリデン基 とカルボキシル基の共役効果で高くなり，水酸化カリウ ムの塩基性で結合が切られ， 6 を経るエピ化が起り易く なったためと考えられる。Erlenmeyer 反応はセリンの

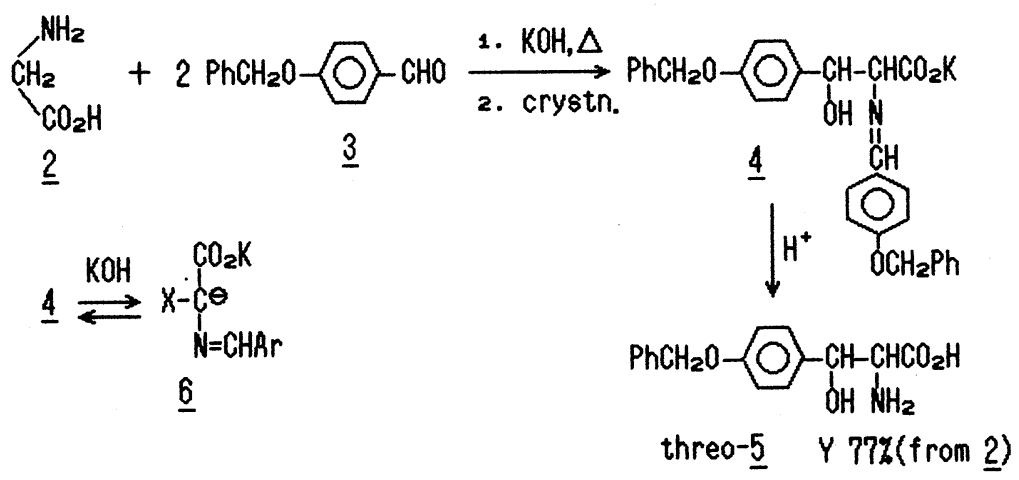

Fig. 4 
Table 1 Epimerization-crystallization of phenylglycine ester salts*.

\begin{tabular}{|c|c|c|c|c|c|c|c|}
\hline \multicolumn{2}{|c|}{ Ester** } & \multirow{2}{*}{ Solvent } & \multirow{2}{*}{ Carbonyl-compd. } & \multirow{2}{*}{$\begin{array}{l}\text { Reaction } \\
\text { time (hr) }\end{array}$} & \multicolumn{2}{|c|}{ 1-TA Salt } & \multirow{2}{*}{$\mathrm{D}$ or $\mathrm{L}$} \\
\hline $\mathrm{R}^{1}$ & $\mathrm{R}^{2}$ & & & & $\mathrm{Y}(\%)$ & $\%$ e.e. & \\
\hline $\mathrm{H}$ & $\mathrm{Me}$ & \multirow{6}{*}{$\mathrm{EtOH}$} & PhCHO (1 eq.) & 24 & 85 & 99 & D-salt \\
\hline $\mathrm{H}$ & $\mathrm{Me}$ & & none & 24 & 64 & 27 & D- \\
\hline $\mathrm{H}$ & Et & & $\mathrm{PhCHO}$ (1 eq.) & 24 & 76 & 95 & $\mathrm{D}-$ \\
\hline $\mathrm{H}$ & $\mathrm{Me}$ & & $\left(\mathrm{CH}_{3}\right)_{2} \mathrm{CO}$ (8 eq.) & 20 & 93 & 99 & $\mathrm{D}-$ \\
\hline $\mathrm{H}$ & $\mathrm{Me}$ & & $\mathrm{PhCOCH}_{3}$ (2 eq.) & 288 & 90 & 95 & $\mathrm{D}-$ \\
\hline $\mathrm{H}$ & $\operatorname{Pr}^{\mathrm{i}}$ & & PHCHO (0.55 eq.) & 144 & 62 & 98 & $\mathrm{~L}^{-}$ \\
\hline $\mathrm{Cl}$ & $\mathrm{Me}$ & \multirow{3}{*}{$\mathrm{MeOH}$} & $\left(\mathrm{CH}_{3}\right)_{2} \mathrm{CO}(50 \%)$ & $?$ & 58 & $>96$ & $\mathrm{D}-$ \\
\hline $\mathrm{Cl}$ & $\mathrm{Me}$ & & none & $?$ & 14 & 85 & D- \\
\hline $\mathrm{HO}$ & $\mathrm{Me}$ & & $\left(\mathrm{CH}_{3}\right)_{2} \mathrm{CO}(50 \%)$ & $?$ & 78 & 99 & $\mathrm{~L}-$ \\
\hline $\mathrm{MeO}$ & $\operatorname{Pr}^{i}$ & $\mathrm{EtOH}$ & $\mathrm{PhCHO}(4.5 \%)$ & $?$ & 50 & $\sim 90$ & $\mathrm{~L}^{-}$ \\
\hline
\end{tabular}

* Ref. 7. ester/solvent $=1 / 10,1$ eq. $\mathrm{L}-(+)-\mathrm{TA}, 20 \sim 25^{\circ} \mathrm{C}$.

** $\mathrm{R}^{1}-\mathrm{O}-\underset{\mathrm{N}}{\mathrm{CHCO}_{2}} \mathrm{H}_{2}^{2}$

光学活性体を与えてはいないが $\alpha$ 位のエピ化を利用し た異性化晶出法の良い例である。

同様の考え方で，フェニルグリシンェステル 7 を無水 アルコール中でベンズアルデヒドやケトン類の各種カル ボニル化合物共存下, L- $(+)$-酒石酸 (TA と略す) で 分割した例がある7)。これは共存するベンズアルデヒド
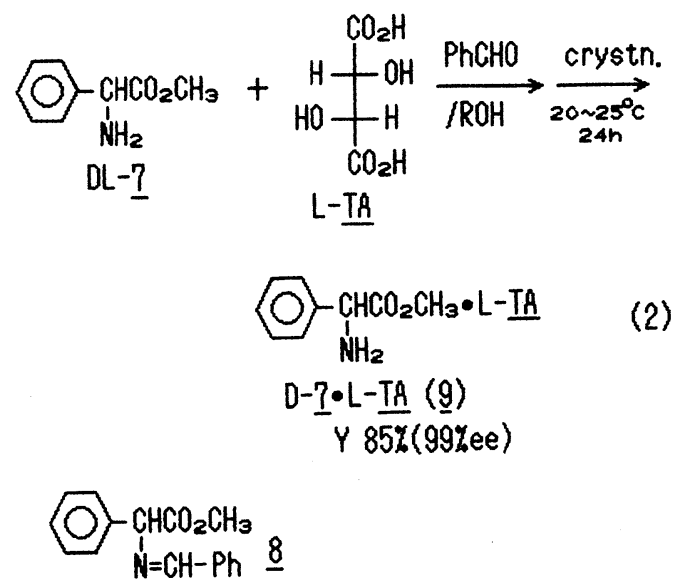

と 7 の形成する $N$-ベンジリデン体 8 がラセミ化 (TA 塩 9 から見ればエピ化）を起し易い点を利用している。 D-7・L-TA の塩 9 を収率 $85 \%$ で得た。他の結果は表 1 の通り。以下, 収率は全て出発原料のラセミ体全量に 対する值を示す。

ケトンやアルデヒド共存下, 置換フェニルグリシンェ
ステルを酒石酸で分割する反応の文献データを基に，定 量的に相関を調べた研究もある ${ }^{8)}$ 。それによると，L-酒 石酸を用いて分割する場合，（1）フェニルグリシンの フェニル基の $p$-位の置換基が嵩高くないほど $\mathrm{D}-フ ェ$ ニルグリシンェステル塩が析出し易くなる，（2）溶媒 極性が増すと D-エステルの塩が溶け易く，（3）共存す るカルボニル化合物が，ケトン類だと D-エステルの塩 が，アルデヒド類だと L-エステルの塩が析出し易くな るなどの傾向がわかった。今後の, 結晶構造との相関研 究が待たれる。

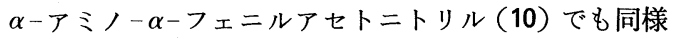
に分割が行えた。Lonyai らはベンズアルデヒド，亜硫 酸水素ナトリウム, 塩化アンモニウムをアンモニア水中

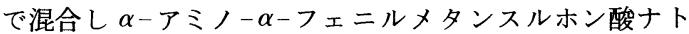
リウム（11）を得て，そのままシアン化ナトリウムで 10 とした。更に 10 をそのままアセトン共存下, 酒石酸で 光学分割し D-10・L-TA の塩を収率 $66 \%$ で得た ${ }^{9)}$ 。こ の場合もアセトンと 10 の形成する 12 がエピ化を促進し ているとも考えられるが，アセトンが必須ではないとい う記述や, 他の研究で酢酸を共存させてェピ化を促進さ せる方法も報告されている(10)。そこで, むしろ 10 の シ アノ基の解離した 13 を経るエピ化を考えた方が良いか むしれない。

このシアノ基の解離という考え方は光学活性なフェネ チルアミン(PEA と略す) を利用した不斉 Strecker 反 応による光学活性な $\alpha$-アミノ酸合成の場合にもあては まる11)。アリール基を含むアルキルケトン 14 と $(S)$ - 

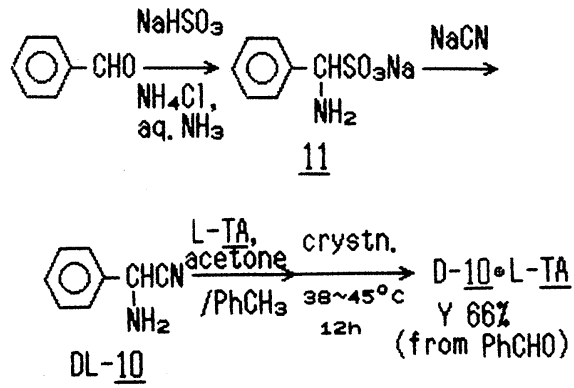

(0)- $\underset{\substack{\mathrm{N}=\mathrm{CHCN}^{-} \\ \mathrm{CH}_{3}}}{-12}$

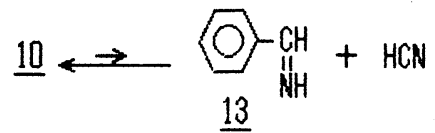

(一)- $\alpha$-フェネチルアミンおよびシアン化ナトリウムを 反応させて光学活性 $\alpha$-アミノニトリル 15 をエピ化晶出 法で得ている((式 4$)$ および表 2 参照)。エピ化の確認
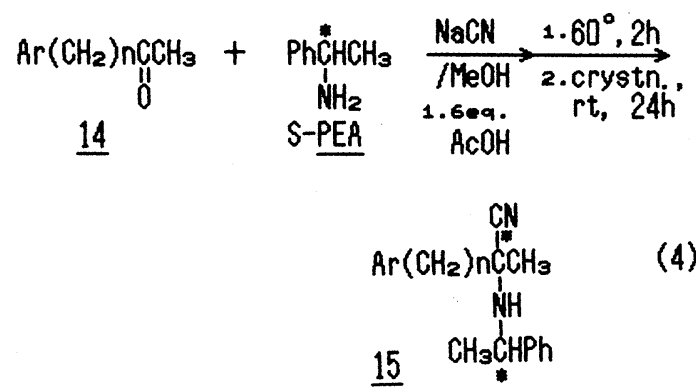

も NMR で行った。即ち,一方のジアステレオマーとし て得られた 15 の結晶を重クロロホルムに溶かし 24 時間 後に測定するといずれも $1: 1$ に近いジアステレオマー 比に変化することを確認した。15 からは対応する光学 Table 2 Yields and configurations of $\alpha-\mathrm{C}$ of 15.

\begin{tabular}{c|c|c|c|c}
\hline \multicolumn{2}{c|}{14} & \multicolumn{2}{c}{15} \\
\hline & $\mathrm{Ar}$ & $\mathrm{n}$ & Yield (\%) & Configuration \\
\hline $14 \mathrm{a}$ & $\mathrm{O}-$ & 1 & 75 & $\mathrm{R}$ \\
$14 \mathrm{~b}$ & $\mathrm{O}-$ & 2 & 75 & $\mathrm{~S}$ \\
$14 \mathrm{c}$ & $\mathrm{CH}_{3} 0-\mathrm{O}-$ & 1 & 84 & $\mathrm{R}$ \\
$14 \mathrm{~d}$ & $\mathrm{CH}_{3} \mathrm{O}-\mathrm{O}-$ & 2 & 91 & $\mathrm{~S}$ \\
\hline
\end{tabular}

活性 $\alpha$-アミノ酸が得られ ((式 5$)$ 参照)，血圧降下剂 として用いられているメチルドーパ(16) もその内の一 つとして合成された。

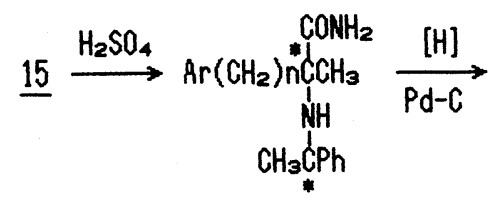
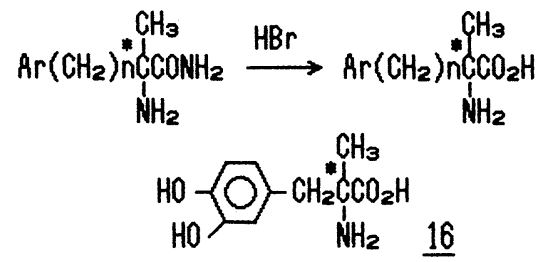

先に示した（式 2）の例は $\alpha-$ アノ酸エステルで, $\alpha-ア ミ ノ$ 酸そのものではなかった。遊離のアミノ酸の ラセミ化は， $N$-アセチルあるいは $N$-ベンジイル誘導体 に変換し, 無水酢酸共存下で酢酸中 $100{ }^{\circ} \mathrm{C}$ に加熱すれ ば, 殆んどの $\alpha-ア ミ ノ$ 酸で確実に進行することが知 られている ${ }^{12)}$ 。しかしこのような条件に塩基性分割郕を 共存させることは困難であった。これに対し鈴木，川合 らはラセミ化条件をトルエン還流に変え, エピ化晶出法 に成功した ${ }^{13)}$ 。 $N$-ベンゾイルフェニルグリシン (17)の $\alpha$-フェネチルアミン塩はトルェン中で 2 時間加熱還流 するとアミノ酸部位が完全にエピ化した。この塩を 3 時 間還流した後, 冷却（彼らの報告には晶析条件は記載さ れていないが徐冷であろう)して，結晶を収率 $68 \%$ で得 た（(式6）参照)。この際 $\alpha-$ フネチルアミンの使用

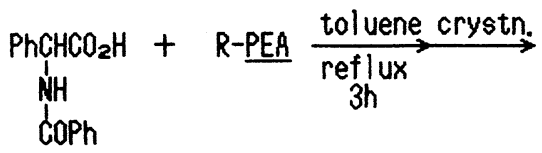

\section{R, S- 17}

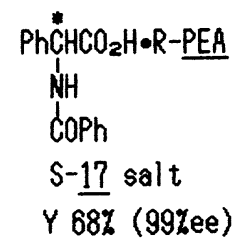

(6)

量を等モル以上に増すと収率が更に増加する傾向が認め られ, 彼らは塩基量が増し 17 の $\alpha$ 位の水素引き抜きに よるエピ化が速められたものと説明している。 分割剤をスルホン酸にして遊離の $\alpha$ ーアミノ酸塩をエ 
ピ化させた例も知られている。山田，千畑らは先ず，各 種の $\alpha-$ アノ酸の種々の鉱酸塩を対応するアミノ酸と サリチルアルデヒド共存下で酢酸中 $100^{\circ} \mathrm{C} に$ 加熱して

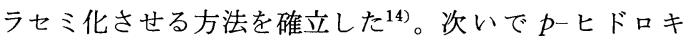

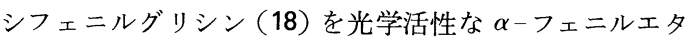
ンスルホン酸 (19) で光学分割するジアステレオマー法 と組み合せ， $\alpha$-アミノ酸を誘導体でないそのままの形 で，エピ化晶出法で光学分割することに成功した ${ }^{15)}$ 。実 用的にも優れた方法と思われる。

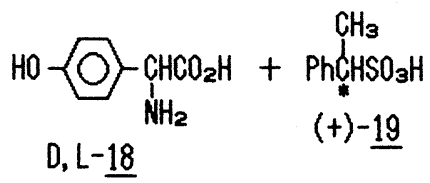

$$
\begin{aligned}
& \underset{\mathrm{ACOH}}{\stackrel{\text { Or }_{\mathrm{OH}}^{\mathrm{CHO}} \text { crystn, }}{\rightarrow}} \stackrel{100^{\circ}, 5 \mathrm{~h}}{\longrightarrow} L-18 \text { salt } \\
& \text { Y 80\% (95\%ee) }
\end{aligned}
$$

また同様の考え方で, 光学分割ではないが DL-アロ イソロイシンから DLーイソロイシンを得たという報告 もある ${ }^{16)}$ 。

ここまでの例で何度か登場したフェニルグリシン誘導 体に比べ光学的に安定な $\alpha-ア ミ ノ$ 酸でも，アミノ酸の カルボキシル基をオキサゾリン環やイミダゾリン環に変 換するとラセミ化が容易になることが知られている ${ }^{17) 。 ~}$ 柴田, 吉川らはイミダゾリン環の中に不斉中心を持たせ ることによってエピ化晶出法に成功した。彼らは, 光学 的に安定なアラニン (Ala) から誘導されるイミノェー

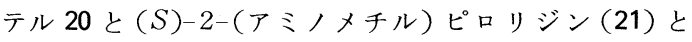
からイミダゾリン誘導体 22 を形成し, ピロリジンなど の塩基存在下で 22 を結晶化させ $(R)$-アラニンに対応

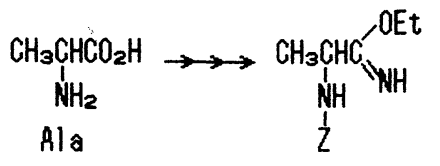

$20 \mathrm{Z}=\mathrm{PhCH}_{2} \mathrm{OCO}-$

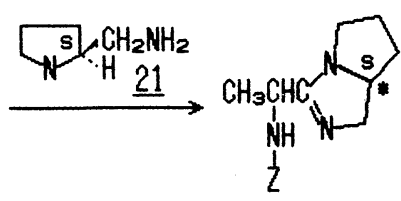

$\underline{22}$
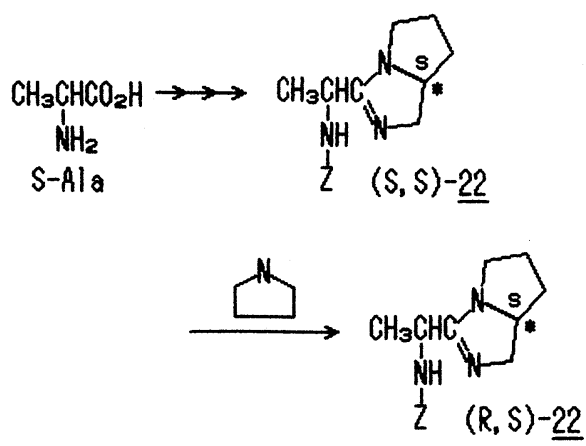

(8)

する $(R, S)-22$ を収率 $86 \%$ で得た ((式 8$)$ 参照 $)^{18)}$ 。

この他, アミノ酸あるいはその誘導体を配位子に含む 金属錯体におけるアミノ酸のエピ化やラセミ化について, Pfeiffer 効果 ${ }^{19)}$ の研究など多くの研究がある ${ }^{20)}$ 。しかし, これらは殆んど光学異性体比の変化, 即ち第 1 種不斉転 換の確認, までで終っている。観点が生体類似反応や触 媒反応という立場にあるためだろう。しかし, 今後, 合 成反応という見方で，この形式のエピ化やラセミ化を利 用した異性化晶出法が成功する可能性も考えられる。

3. 3. シアンヒドリン誘導体シアンヒドリンのシ アノ基は非常に解離し易く（式 9）のような互変異性化 を起し易い。これをエピ化に利用して光学活性体をエピ 化晶出法で得る例がいくつか知られている。
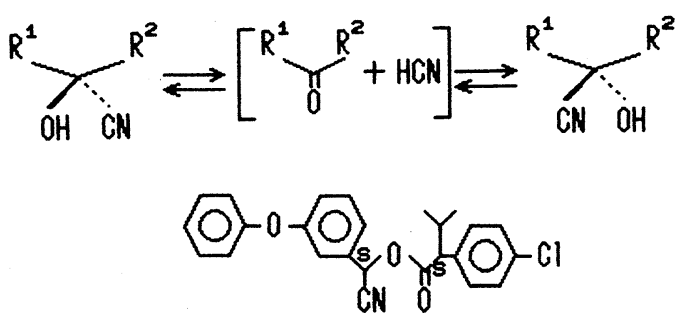

$\underline{23}$

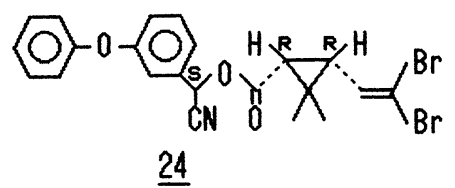

強力な殺虫剤・殺ダ二風の合成ピレスロイドは一般に, 不斉中心を複数個持っており, それらの内の唯一の光学 異性体が有効である。この有効な光学異性体を選択的に 合成することが合成上の重要なポイントである。ピレス ロイドの中で, フェンバレレート（23）やデカメスリン （24）はシアンヒドリン構造を含むため，この部分の不 
斉炭素の分割においてシアノ基の解離によるエピ化と結 晶化を組み合せたエピ化晶出法が知られている ${ }^{21,22)}$ 。例 えば 23 はアルコール中で触媒量のトリエチルアミンを 添加することによって，他方の不斉中心の不斉を失うこ となく，シアンヒドリン部位のみをエピ化させることが できた。これに晶析を組み合せ必要な光学異性体 $(S, S)$ -23を得ている ((式 10) 参照 $)^{21)}$ 。

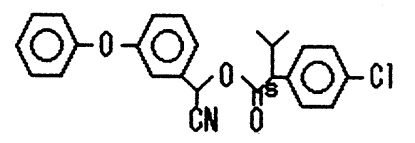

$(R, S)-\underline{23}+(S, S)-\underline{23}$

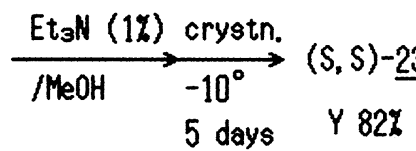

ジアステレオマーを経由して光学分割しようとする場 合，光学分割したい化合物と分割剂を塩形成あるいは土 ステル形成などで結合させることが多い。これに対し， 23 や 24 に用いられる $\alpha$-シアノ-3-フェノキシベンジ ルアルコール (25) を, アルコール用の光学分割剤 26 と エーテル結合させて, 得られたジアステレオマー 27 を エピ化晶出法で光学分割した例もある ${ }^{23)}$ 。

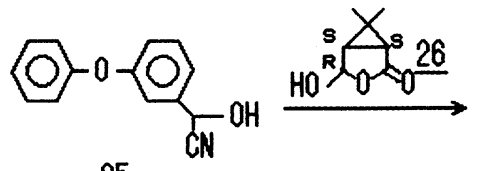

$\underline{25}$

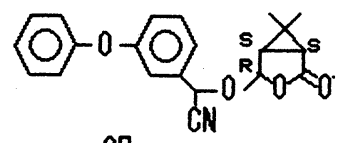

((式 12 ) 参照)。晶析に溶媒留去を用いている点も興味 樑い。

3.4. その他の例 異性化晶出法に利用されるエピ 化やラセミ化は非常に速く, しかも可逆的である（互変 異性)。この条件を満たす異性化は全てェピ化晶出法が

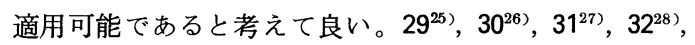
$33^{29)}$ はエピ化晶出法で光学分割された例であるが，い ずれもプロトン酸として酸性度が高いものである。解離 し易い水素原子を太字で示した。

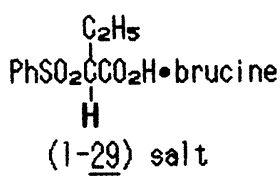<smiles>O=CC1Cc2ccccc2NC1=O</smiles>
(d- $\underline{31}$ ) salt $(d-\underline{30})$ salt

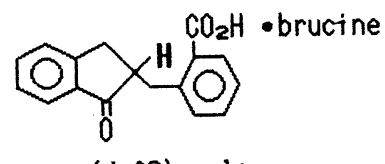

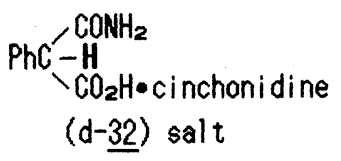

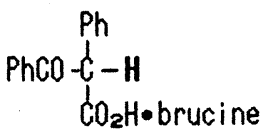

$\underline{33}$ salt

2. で引用した D-グルコースの開環一閉環によるエピ 化も今後の応用が考えられる。

この他, エナミンやオキサゾリン誘導体を経由する方 法も不斉転換とされている30)。しかしこれらはむしろ不 斉誘起反応と呼ぶ方がふさわしいと思われる。

\section{4. ラセミ化優先晶出法}

この方法は結晶化する化合物がエナンチオマーである 場合の光学分割 ${ }^{31)}$ で, 不斉中心が溶液中で容易にラセ ミ化し平衡に達する場合に適用できる（図 5 参照）。従 来の, いわゆる優先晶出法では, 一方のエナンチオマー のみが必要という, 実際にはよくあるケースでも, 他方 のエナンチオマーが同時に分割されるため, これをラセ ミ化させて原料に戻す工程が必要である。しかも通常 1 回の晶析操作で得られる量は $5 \%$ 前後で効率が悪い(図 6 参照)。これに比べラセミ化優先晶出法は, 少量の種 晶で，いずれのエナンチオマーも自在に得られ，しかも 1 回の操作で $80 \%$ 前後の収率で得られるので効率が良 い。エピ化晶出法に比べても, 光学分割剤など何らかの 不斉源が等モル必要であったのに対し, それが不要で自 分自身が不斉源になる点で有利である。 


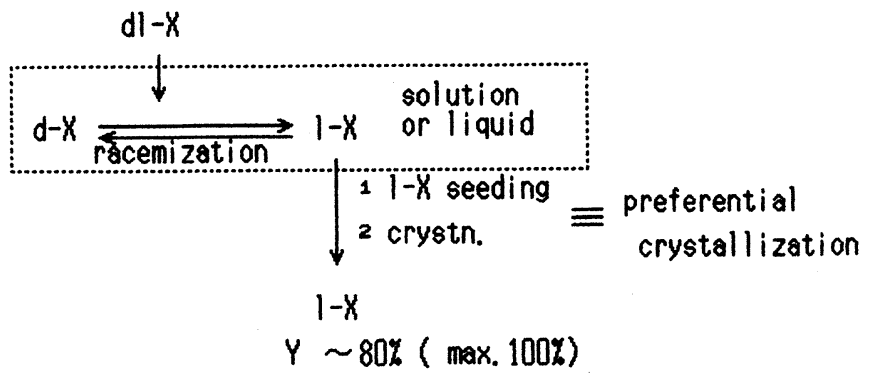

Fig. 5 An example of racemization-preferential crystallization method.

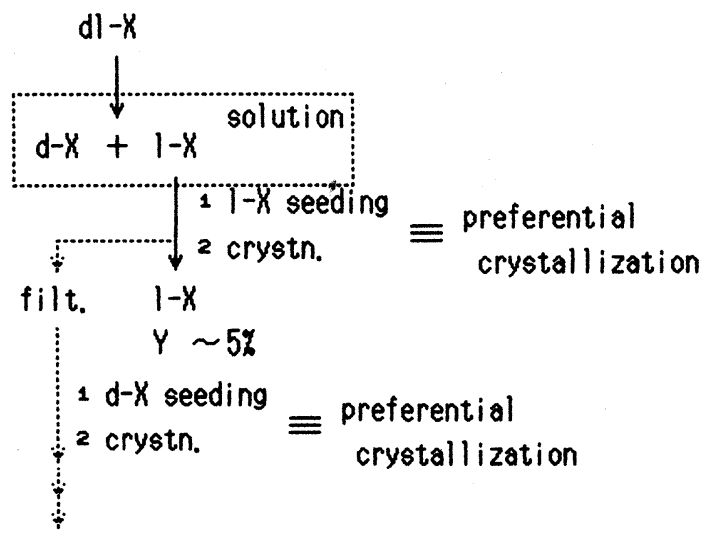

Fig. 6 An example of preferential crystallization method.

4.1. ラセミ化優先晶出法の難しさこのように実 用的に優れた方法であるにもかかわらず，合成法として

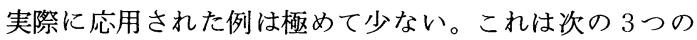
難しさによるものと思われる。

第一の難しさは目的の化合物が結晶であること，しか もラセミ混合物 (racemic mixture あるいは conglomerate) である必要があることである。ラセミ体 (racemic moditicątion) の結晶はその性質からラセミ混合物, ラ セミ化合物 (racemic compound), ラセミ固溶体 (solid solution）の 3 種に分類される32)。これらの内でラセミ 混合物である確率は 5 10\% といわれ ${ }^{33)}$, かなり確率 が低い。ラセミ混合物であることの判定は，ラセミ体と 光学活性体の結晶を調製し，それらを用いて測定した融 点図 (図7参照), 溶解度図, IR スペクトルなどから行 える ${ }^{34)}$ 。しかし最終的には実際に優先晶出するかどうか 試す必要がある。ラセミ混合物であっても優先晶出の起 し易さに差があり, ラセミ体が光学活性体より融点が $20 \sim 30^{\circ} \mathrm{C}$ 低く, 溶解度が約 2 倍である場合が望ましい。 これは定性的な解釈としてはラセミ体の結晶中よりも光 学活性体の結晶中の方が分子間力が強く，しかも余り強 過ぎないことを意味している33)。結晶や溶液という多分 子系での分子間力の計算が可能になればラセミ混合物か どうかの予測も可能になると思われるが，現在は未だ容 易ではない。

このように優先晶出可能な化合物を探すことは容易で ないが，分子間力の近似計算による予測や，経験的な予 測を入れると，上の確率は 3 倍程度までは上げられる。 経験的な傾向として，（1）アミノ酸は中性ないし弱ア ルカリ性の塩にする ${ }^{35)}$ ， あるいはアリールスルホン酸塩 にする ${ }^{36)}$ （2）アミン類はケイ皮酸塩にする ${ }^{37) ，(3) ~}$ カルボン酸はアンモニウム塩 ${ }^{37)}$ ，あるいはェステルにす $ろ^{36)}$ ，等によってラセミ混合物である確率が高まる。優 先晶出可能な化合物を探す研究は各地で現在も続けられ
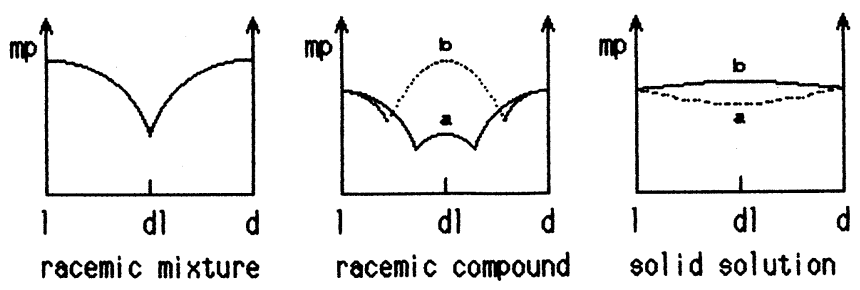

Fig. 7 Examples of binary phase diagram. 
ており，この化合物の数は着実に増えている。

第二の難しさはラセミ化が起り易い必要があり，しか も起り易過ぎない必要がある点である。光学活性化合物 のラセミ化は, 通常, 不斉中心の原子に拉いて結合が解 離する必要があり，これが制約条件になる。また余りラ セミ化が容易であると光学活性体としての安定性が無く なり, 単離しにくくなってしまう。結局, 高温条件やラ セミ化剤の添加などによってのみラセミ化が速くなる必 要がある。

第三の難しさは優先晶出する際の結晶化といら工学的 操作に未解明な点が多いことである。溶解度曲線の上に 過飽和溶解度曲線がありこれ以上の濃度では結晶の核発 生が起ること，更にその上に，核発生が一気に進む第 2 の過飽和溶解度曲線が存在すること, 核から結晶成長が 進む場合の各種の結晶成長のモデルや理論が提案されて いること等 ${ }^{38)}$, 晶析操作において参考になる知見は多 い。だが，例えば優先晶出を安定に進めるには図8の準 安定領域内で結晶を成長させる必要があることが判って も, その準安定領域が共存する不純物の量や種類, 反応 器の壁面の状態や攪汼のスピード等で広くなったり狭く なったりするので, 各々のケースで充分な検討が必要に なる。過飽和溶解度曲線を求めるだけでも大変であ $る^{38 \mathrm{~b})}$ 。また, 種晶を過飽和溶液に添加する際の種晶粒 度についても結晶成長速度が結晶の各面毎に違い，また 結晶形毎でも異なるため，物理的に細かくすることが望 ましい場合 ${ }^{39)}$ もるし，逆の場合40) もあるというよう に各々のケースで異なる。

この難しさに対するには先ず充分な条件検討も勿論必

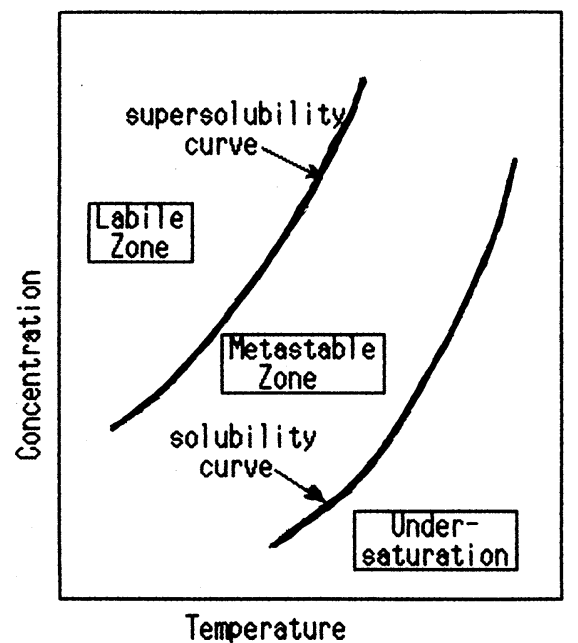

Fig. 8 Supersolubility curve and regions.
要だが，ラセミ混合物の中から準安定領域の広い化合物 で, 結晶成長速度が速い結晶形のものを，更に選ぶこと である。

その他，ラセミ化の速さと結晶化の速さの調整の問題 もあるのでエピ化晶出法に比べるとラセミ化優先晶出法 は難しいといえる。しかし私たちのグループを含め成功 例がいくつか報告され始めた。今後この手法の例は更に 増えるものと思われる。以下にこれまでに知られている 例を紹介する。

4. 2. 歴史的な例 ラセミ化優先晶出法の最初の例

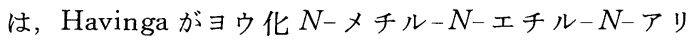
ルアニリニウム (34) で成功した。彼はこの現象を自発 的光学活性体生成 (spontaneous formation of optical active substance) と呼びその異常性を強調した。34 は クロロホルム溶液中でゆっくりとラセミ化し，また結晶 はラセミ混合物であったため, 34 のクロロホルム溶液 を実に 2 ケ月かけて結晶化させ，収率 $50 \%$ 前後で光学 活性体の 34 を得た ${ }^{41)}$ 。

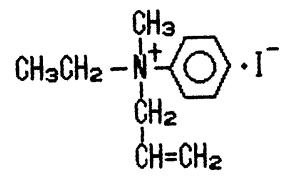

$\underline{34}$

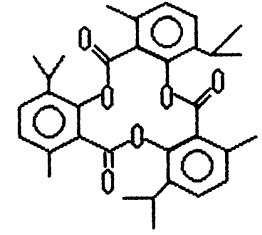

$\underline{35}$
また Powell はトリチモリド（35）について，その配 座異性由来の光学活性体を溶液からの結晶化で得た ${ }^{42)}$ 。 34 や 35 はいずれむ溶液にすると短期閒でラャミ化L.て しまう光学的に不安定な化合物であるため光学活性化合 物としての利用は考えにくいが，これらの実験がラセミ 化優先晶出法の可能性を実証したという意義は大きい。

4. 3. $\alpha$-アミノ酸誘導体 リジンの原料になる $\alpha-$ アミノーยーカプロラクタム $(36)$ のニッケル錯体 37 は優 先晶出し, しかもエタノール中でカリウムエトキシドな どの塩基と共存させると容易にラセミ化した ${ }^{43)}$ 。このラ セミ化条件下で 37 の過飽和溶液に種晶を添加しエタ， ールを留去して結晶化を促進させ, 収率 $50 \%$ で光学活 性な 37 を得ている ((式 13$)$ 参照)。この光学活性な 37 は容易に光学活性リジンに導かれた。光学活性リジンを 共存させて 37 をセミ化優先晶出させると, この分割 法が更に安定化できるという研究も知られている ${ }^{44)}$ 。

本郷，千畑らは $N-$ アシル- $\alpha-$ アミノ酸が無水酢酸存 在下で加熱すると容易にラセミ化する点に着目し，N- 
<smiles>NC1CCCNC1=O</smiles>

$\underline{36}(\equiv A C L)$
$(\mathrm{ACL})_{3} \mathrm{NiCl}_{2} \cdot \mathrm{EtOH}$ $\underline{3 ?}$

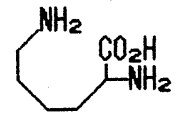

Lysine

\section{D, L-37 $\underset{2 \text { EtOH relux with KOEt }}{\stackrel{1}{2}-3 \text { ? seeding }}$ \\ 3 EtOH evaporn.}

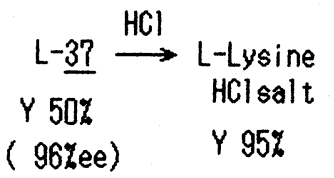

ベンゾイルフェニルグリシン， $N$-ブチリルプロリン， $N$-アセチルロイシン (38) 等でラセミ化優先晶出法を試 みた。特に 38 については, 酢酸中無水酶酸共存という 条件で $100{ }^{\circ} \mathrm{C}$ から $40^{\circ} \mathrm{C}$ まで, 6 時間かけて種晶から成 長させ収率 $70 \%$ で光学活性な 38 を得ることに成功し た（(式 14）参照 $)^{45) 。}$

$$
\begin{aligned}
& \left(\mathrm{CH}_{3}\right)_{2} \mathrm{CHCH}_{2} \mathrm{CHCO}_{2} \mathrm{H} \\
& \mathrm{NHCOCH}_{3} \\
& \text { D. L- } \underline{38}
\end{aligned}
$$

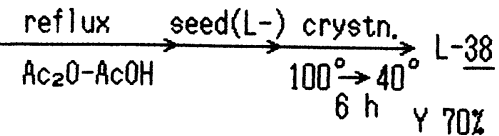

$$
\begin{aligned}
& \text { (99\%еe) }
\end{aligned}
$$

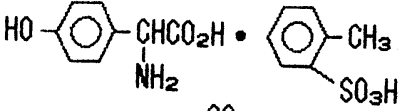

$$
\begin{aligned}
& \underline{39}
\end{aligned}
$$

更に彼らは研究を進め遊離のアミノ酸の塩でもラセミ 化優先晶出法に成功した。前の章で述べた遊離のアミ， 酸塩がラセミ化する条件 ${ }^{14)}$ をこでも活用し， $p-$ ヒド ロキシフェニルグリシンの各種の塩の中から特に安 定に優先晶出する化合物として, 0 -トリルスルホン酸の

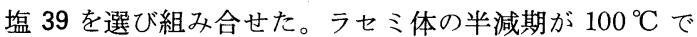
1 時間程度で若干遅いため高温で結晶化させている。 $100{ }^{\circ} \mathrm{C}$ で 39 の優先晶出が進行中の $p$-ヒドロキシフェニ ルグリシン過剰のスラリーに，o-トリルスルホン酸の無 水酶酸溶液を非常にゆっくり $(5 \mathrm{ml} / \mathrm{hr})$ 滴下し, 途中で ラセミ化を促進するサリチルアルデヒドを追加するとい った工夫を加え効率を上げ，収率約 $60 \%$ まで到達し た ${ }^{46)}$ 。実用的な観点からは先に述べたエピ化晶出法 ${ }^{15)} の$ 方が容易かと思われる。
Table 3 Melting points of $41^{\prime} \mathrm{s}$.

\begin{tabular}{c|l|c|c}
\hline \multirow{2}{*}{41} & \multirow{2}{*}{$\mathrm{X}$} & \multicolumn{2}{|c}{$\mathrm{mp}\left({ }^{\circ} \mathrm{C}\right)$} \\
\cline { 2 - 4 } & & $\mathrm{DL}$ & $\mathrm{L}$ \\
\hline $\mathrm{a}$ & $p-\mathrm{Cl}$ & 65.5 & 88.5 \\
$\mathrm{~b}$ & $m-\mathrm{Cl}$ & 34 & 57 \\
$\mathrm{c}$ & $o-\mathrm{Cl}$ & 39.5 & 57.5 \\
$\mathrm{~d}$ & $p-\mathrm{Br}$ & 99 & 121.5 \\
$\mathrm{e}$ & $\mathrm{H}$ & 38 & 53 \\
$\mathrm{f}$ & $p-\mathrm{Me}$ & 78 & 100.5 \\
$\mathrm{~g}$ & $p-\mathrm{MeO}$ & 59.5 & 78 \\
$\mathrm{~h}$ & $o-\mathrm{OH}$ & 38.5 & 52.5 \\
$\mathrm{i}$ & $o-\mathrm{CN}$ & 105 & 68.5 \\
$\mathrm{j}$ & $p-\mathrm{NO} 2$ & 61.5 & 66 \\
$\mathrm{k}$ & $p-\mathrm{AcNH}$ & 126 & 75.5 \\
\hline
\end{tabular}

筆者らは, 新しい甘味剤アスパルテームの主要な原料

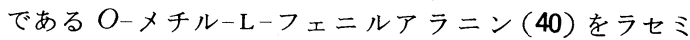
化優先晶出法を用いるルートで光学分割した。 $\alpha$-アミ ノ酸エステルはラセミ化が遅いため, 塩基性条件下でラ セミ化の速い $N$-ベンジリデン体 41 を選び，各種誘導

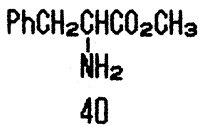

40

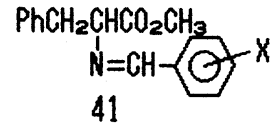

41
体を合成し優先晶出の可能性を調べた。表 3 に, それら の化合物の融点比較の一部を示した。これらの中で安定 に優先晶出する $41 \mathrm{a}(\mathrm{X}=p-\mathrm{Cl})$ を, イソプロピルアル コール中で, $\operatorname{DBU}(1,8$-diazabicyclo (5.4.0)-7-undecene）を塩基として共存させてラセミ化優先晶出させ 収率 $76 \%$ で光学活性体を得た。種を変えれば D 体，L 体が自在に選択できることも確認した ${ }^{47) 。 ~}$

$41 \mathrm{a}$ の $\mathrm{L}$ 体は希塩酸で穏和に処理して, 目的の $O-メ$

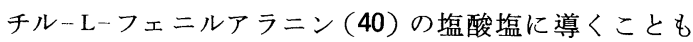
できた（(式 15）参照)。
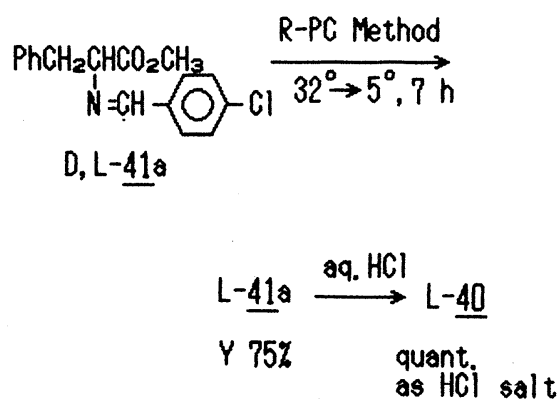

(15) 
4.4. $\boldsymbol{\alpha}$-芳香族カルボン酸エステル 筆者らは光学 活性な抗炎症剂ナプロキセン（42）の合成においてもラ セミ化優先晶出法を試みた。ラセミ体は $\beta$-メトキシナ フタレンから， $\alpha$-クロロスルフィド 43 を用いる Friedel - Crafts 反応で 2 工程で得ることができた ${ }^{48)}$ 。そこで得
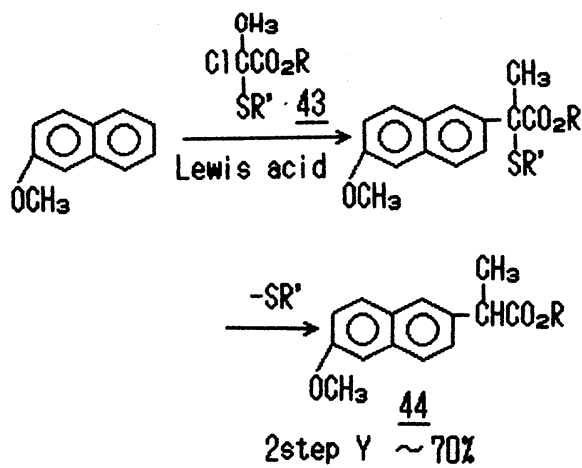

(16)

られたラセミ体のエステル 44 を調べると，幸いメチル エステル $44 \mathrm{a}$ やエチルエステル $44 \mathrm{~b}$ が優先晶出可能で あることが判った。また $44 \mathrm{a} や 44 \mathrm{~b}$ はアルコキシド溶 液をラセミ化剤として用いると，42に比べ格段にラセ ミ化が速いことも確められた（表 4参照）ので, 早速, 優先晶出と組み合せてみた。初めは収率 $5 \%$ 程度と効 率的でなかったが, 種晶粒度, 種晶量, 㩫抖速度, 晶析 時の過飽和度等の検討を経て 1 回の反応で収率 $89 \%$ ま で向上させることができた（(式 $17 ）$ 参照 $)^{49)}$ 。

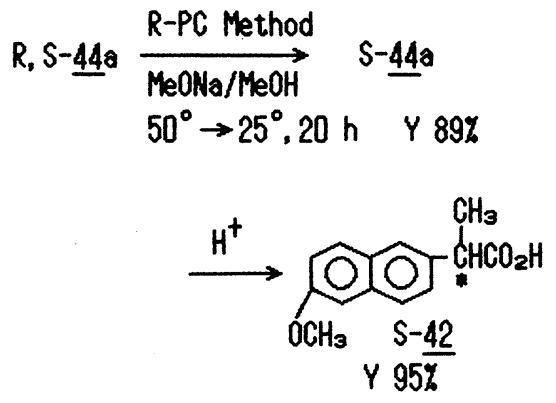

ラセミ化優先晶出法（エピ化晶出法も同じだろう）は 結晶化を用いるため, 目的物が液体の場合は利用しにく いが，誘導体を少し工夫すれば可能である。そりような 例として，筆者らの 2-フェニルプロピオン酸 (45) を示 すことができる。45 は沸点 $260 \sim 262{ }^{\circ} \mathrm{C}$ で室温で液体で あるが， $\beta$-ナフチルエステル 46 にすることによって結 晶とし, しかも優先晶出も可能にできた。ラセミ化の速
Table 4 Racemization of naproxen derivatives.

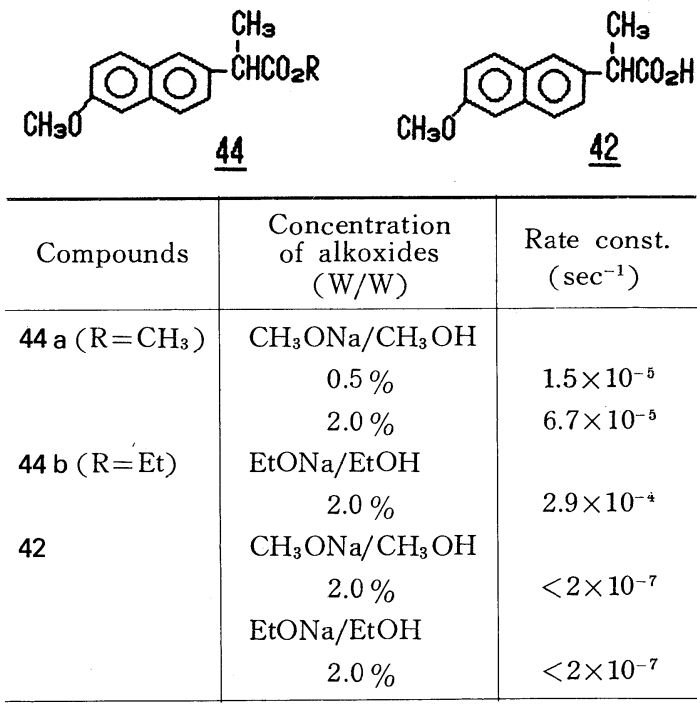

* Compds $50 \mathrm{mg}$ in $10 \mathrm{ml}$ of $\mathrm{RONa} / \mathrm{ROH}$; determined by $[\alpha]_{\mathrm{D}}^{20 \sim 21}$.

度は前の例と同様に，エステルに変換したことによって 非常に速められラセミ化優先晶出が可能になった。実際 にDBUをラセミ化剤として収率 $82 \%$ で 46 の光学活 性体を得ることができた ((式 18$)$ 参照 $)^{50)}$ 。45 のの加水 分解は酸性条件で行うことによって立体保持で進んだ。
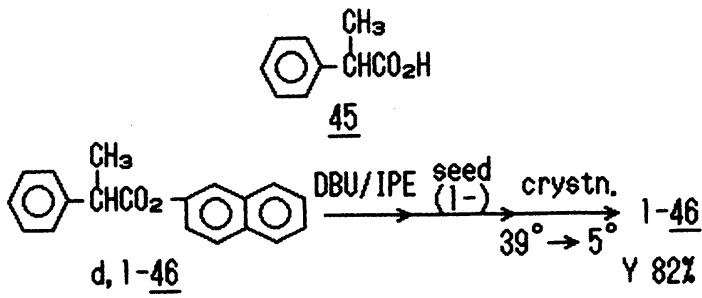

(18)

4. 5. 溶融状態からの結晶化の例 ラセミ化優先晶 出法をつきつめていくと溶液からの結晶化でなく，溶融 状態からの結晶化でも可能と考えられる。ただし結晶化 が融点で一気に進むためラセミ化速度も非常に速い必要 があり，またそのような高温でも熱的に安定な化合物で あることも要求される。

Pincockらの $1,1^{\prime}$-ビナフチル (47) での光学分割はこ の例になる。47 は軸不斉による光学異性体が存在し, 異性化は加熱による軸回転で起る。47 のラセミ体 (mp $\left.145^{\circ} \mathrm{C}\right) を 150{ }^{\circ} \mathrm{C}$ に加熱して全て溶かしてから，例えば $S$ 体の $47\left(\mathrm{mp} 159^{\circ} \mathrm{C}\right)$ を種晶として加え, $150^{\circ} \mathrm{C}$ を 8 時 間保つことによって $S$ 体を収率 $80 \%$ 以上で得た ${ }^{51)}$ 。 


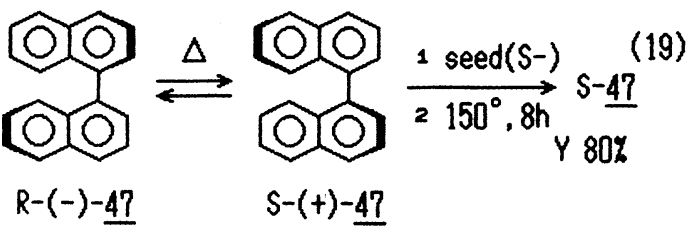

“溶液に種を加え，あとは結晶化させるだけ"というラ セミ化優先晶出法の特長の端的な例といえる。この方法 を応用すれば精製などに用いられるゾーン・メルトを 1 回かけるだけでラセミ体を全て光学活性体に変えること も可能と思われ, 今後が楽しみな分野と言えよう。

\section{5. おわりに}

筆者は学生時代, 配座異性体や幾何異性体間の安定性 の比較も研究し, 各種の異性化も扱った ${ }^{52)}$ 。それらの中 で異性化に伴って結晶が析出し，平衡時の異性体比のデ ータとしては使えなかったが，それまで得にくかった配 座異性体が簡便に得られたことがあった。その時のキラ キラと輝く結晶の印象は強く，異性化反応と晶析を組み 合せるだけでもかなりのことができるという印象だけが 残った。その後の実用的合成反応の研究の際も, この考 え方は役立った。本文では，この異性化晶出法の光学分 割への利用に限って紹介したが，合成全般に有効で，場 合によっては意識せずに利用されている手法だろうと思 われる。光学分割を含め汎く利用していただく際にこの 論文が少しでも役立てれば幸いである。

最後に, 本研究には社内社外でご協力やご助言を多数 の方々からいただいている。大変深く感謝いたします。 また，本研究にご理解をいただき本報の発表を許可され た浦 康一研究所長に厚くお礼申し上げます。

（昭和 61 年 2 月 5 日受理）

\section{文献}

1）全般的な参考文献

a) J.Jacques, A. Collet, S. H. Wilen, "Enantiomers, Racemates, and Resolutions", John Wiley \& Sons (1981)

b) E.E. Turner, M. M. Harris, Quart. Rev. Chem. Soc., 1, 299 (1947)

c) J.D.Morrison, H.S. Mosher, 井上，原田訳， 「不齐合成」, 東京化学同人 (1973)

d) 芝 哲夫, 「立体化学」, 化学同人 (1971)

2) A.P.Dubrunfaut, C. R. Acad. Sci., Paris, 23, 38 (1846)

3) 1c) p 28 および 1d) p 52-55

4a) 1b) および M. M. Harris, Progress in Stereochem., 2, 157 (1958) b) 類似の言葉として “光学活性化”，（optical activation）もあるが用いられている例は少ない。ま た 1c) では “不斉変換”と訳している。

5) H. Krauch, W. Kunz, "Organic Name Reactions", John Wiley \& Sons, p. 152 (1964)

6) W. A. Bolhofer, J. Am. Chem. Soc., 76, 1322 (1954)

7) J. C. Clark, J. Chem. Soc., Perkin 1, 1976, 475

8) A. Lopata, F. Faigl, E. Fogassy, F. Darvas, J. Chem. Res., Synop., 1984, 324 ; C. A., 102, $167133 \mathrm{~g}$ (1984)

9) P. Lonyai, G. Toth, F. Garamszegi, G. Lehoczky, A. Hunyadi, G. Csermely, Hung. Teljes, 13, 579 (1975) ; C. A., 89, $6557 \mathrm{w}$ (1978)

10) G. J. Mathews, B. Calo, USP, $3,808,254$ (1971)

11) K. Weinges, K. Gries, B. Stemmle, W. Schrank, Chem. Ber., 110, 2098 (1977)

12) 千畑一郎, 戸井浤二, 山田茂樹, 化学総説, 4, 252 (1974)

13）鈴木洸次郎，清岡俊一，宮川敏夫，川合 明，日 化誌, 1980, 287

14) S. Yamada, C. Hongo, R. Yoshioka, I. Chibata, J. Org. Chem., 48, 843 (1983) ; C. Hongo, R. Yoshioka, M. Tohyama, S. Yamada, I. Chibata, Bull. Chem. Soc. Jpn., 56, 3744 (1983)

15）吉岡龍蔵, 本郷主税, 當山正副, 山田茂樹, 千畑 一郎, 日本化学会第 49 回春季年会，予稿集 II， 1148 (1984)；日特開昭 58-52254 (1983)

16) C. Hongo, R. Yoshioka, M. Tohyama, S. Yamada, I. Chibata, Bull. Chem. Soc. Jpn., 57, 1328 (1984)

17) K. Yonetani, Y. Hirotsu, T.Shiba, ibid., 48, 3302 (1975)

18) S. Shibata, H. Matsusita, K. Kato, M. Noguchi, M. Saburi, S. Yoshikawa, ibid., 52, 2938 (1979)

19) L. A. Mayer, R. C. Brasted, J. Coord. Chem., 3, 85 (1973)

20) S. Yoshikawa, M. Saburi, M. Yamaguchi, Pure Appl. Chem., 50, 915 (1978) ; K. Harada, K. Shiono, S. Nomoto, Chem. Lett., 1980, 1271 ; M. Yamaguchi, Y. Masui, M. Saburi, S. Yoshikawa, Inorg. Chem., 21, 4138 (1982), etc..

21）サ.バ.ソロウェイ，チ.ヘ.タイマン，日特開 昭 54-59248 (1979)

22）ジ.ワルナン，ジ.プ.マレシャル，フ.コスケ，日 特開 昭 52-148040 (1977)

23）ジ.マルテル，ジ.テシュ，ア.テシュ, 日特開 昭 54-130557 (1979)

24) F. Toda, K. Tanaka, Chem. Lett., 1983, 661

25) W. C. Ashley, R. L. Shriner, J. Am. Chem. Soc., 54, 4410 (1932)

26) H. Leuchs, J. Wutke, Ber., 46, 2425 (1913) 
27) H.Leuches, Ber., 54, 830 (1921)

28) M. K. Hargreaves, M. A. Khan, J. Chem. Soc., Perkin II, 1973, 1204

29) M. A. Kahn, A. M. Kahn, J. Chem. Soc. Pak., 1, 75 (1979) ; C. A., 92, 110436 d (1979)

30) H. Matsushita, S. Yoshikawa, et al., Bull. Chem. Soc. Jpn., 51, 862 (1978) ; S. Shibata, S. Yoshikawa, et al., ibid., 55, 3546 (1982)

31) A. Collet, M. J. Brienne, J. Jacques, Chem. Rev., 80, 215 (1980)

32) R. M. Secor, ibid., 63, 297 (1963)

33) 1a) p. $43-88$

34) 野平博之, 化学増刊, 97, 165 (1982)

35）明石武和, 化学と生物, 4, 598 (1966)

36）未発表

37）西郷和彦，有合化，43，1144（1985）

38a）八幡屋 正, 新化学工学講座, 結晶化, 日刊工業 新聞社 (1960)

b) 村田芳治, 化学工学, 44, 621 (1980)

39）スレオニンについて，大槻 理，化学機械技術, 34, 31 (1982)

40） o-アセチルパントラクトンについて, 稲垣正博, 山本勝正, 片岡幾久江, 赤沢 修, 薬学雑誌, 97, 151 (1977)

41) E. Havinga, Biochim. Biophys. Acta, 13, 171 (1954) ; E. Havinga, Chem. Weekblad., 38, 642 (1941) ; C. A., 36, 5790 (1942)
42) A. C. D. Newman, H. W. Powell, J. Chem. Soc., 1952, 3747

43) S. Sifinides, W. J. Boyle, Jr., J. F. Peppen, J. Am. Chem. Soc., 98, 3738 (1976); W. J. Boyle, Jr., S. Sifinides, J.F. Peppen, J. Org. Chem., 44, 4841 (1979)

44) S.Sifinides, M. Lahav, W. J. Boyle, Jr., USP, 4,259,239 (1981)

45) C. Hongo, S. Yamada, I. Chibata, Bull. Chem. Soc. Jpn., 54, 3286, 3291 (1981)

46) C. Hongo, M. Tohyama, R. Yoshioka, S. Yamada, I. Chibata, ibid., 58, 433 (1985)

47）小原義夫, 松本浩郎, 高橋泰裕, 土屋脩二, 新井 和孝, 日本化学会第 53 回春季年会, $2 Z 48$ (1986)

48）新井和孝, 有合化, 39, 374 (1981); K. Arai, T. Ohara, T. Izumi, Y. Takakuwa, Tetrahedron Lett., 24, 1531 (1983)

49）新井和孝, 小原義夫, 飯泉豊子, 高桑保夫, 第 47 回有機合成シンポジウム要旨集 p.64 (1985)

50）高橋泰裕, 小原義夫, 松本浩郎, 土屋脩二, 新井 和孝, 未発表

51) R.E. Pincock, K. R. Wilson, J. Am. Chem. Soc., 93, 1291 (1971)

52) K. Arai, H. Iwamura, M. Ōki, Bull. Chem. Soc. Jpn., 48, 3319 (1975)

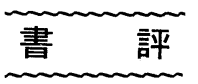

昨今大学の新入生に有機化学を教える際に常に心悩ま される問題の一つは, 大学と高等学校の有機化学をどう 繋いで行ったらよいであろうかと云うことである。

本書はこのような間隙をつなぐための一つの適切な教 科書 (理科系学生には, あるいは副読本) と思われる。 著者が意図しているように内容は高等学校の化学のレベ ルよりはやや高い。有機化学の基礎的な知識を一通り教 科書風に網羅しながら, 一方では有機化学の身近かなト ピックスを適所に織り込みながら，いかに有機化合物が 我々の日常生活とかかわり合いが哚いか，またその恩恵 を受けているのかを自然に理解できるように仕向けられ ている。

内容は第 1 章, 原子と分子の世界一有機化合物の骨組 み, 第 2 章, 有機資源の循環, この章では地球上の炭素 資源の循環（石油化学から $C_{1}$ 化学まで）のあり様を概 観している。第 3 章, 人間が作って使う分子では合成緎

$$
\begin{aligned}
& \text { 野崎 一著 } \\
& \text { 化学同人発行 定価 } 2,000 \text { 円 }
\end{aligned}
$$

維, 洗剤, 色素等の解説からそうたものの発がん性, 催 奇性等についての解説もなされている。第 4 章, 生命を 支える分子一生物の営みを分子の世界に見るでは生体の 構成に重要な炭水化物, 核酸, アミノ酸, 蛋白質等の代 謝についての解説が書かれている。各章のはじめには「こ の章のねらい」が示されており，また各章の終りには「ひ とくち用語解説」がついているように親しみ易く，わか り易くという著者の意図は本の隅々まで配慮されていて 終始読者の興味をひきつけている。

本書は有機合成化学の分野で世界的な研究業績をおさ めている著者による数少ない有機化学の解説書である。

文科系, 理科系を問わず教養課程の学生には一度読ん でほしい本の一つである。また専門課程や大学院の学生 にも有機化学と社会とのつながりを再度認識するために も一読一覧されることをお勧めしたい。

(中川昌子) 